\title{
Assessing the impact of sulfur concentrations on growth and biochemical composition of three marine microalgae
}

\author{
Tomásia Fernandes $^{1,2} \cdot$ Igor Fernandes ${ }^{1,2} \cdot$ Carlos A. P. Andrade ${ }^{2,3,4} \cdot$ Nereida Cordeiro $^{1,2,4}$ (I)
}

Received: 20 May 2019 / Revised and accepted: 9 October 2019

(C) Springer Nature B.V. 2020

\begin{abstract}
The elemental stoichiometry, growth and biochemical composition of Nannochloropsis gaditana, Rhodomonas marina and Isochrysis sp. were studied in batch cultures against different nitrogen and sulfur molar ratios $(\mathrm{N}: \mathrm{S})$ imposed in their surroundings. In $N$. gaditana, treatments with low N:S lead to an increase in carbon:sulfur $(\mathrm{C}: \mathrm{S})$ and $\mathrm{N}: \mathrm{S}$ molar ratios up to 95 and $81 \%$, respectively. This was reflected in lipid and protein contents which increased up to 67 and 55\%, respectively. Moreover, polyunsaturated fatty acids, as well as its precursors, increased in low $\mathrm{N} / \mathrm{S}$ treatments. In $R$. marina, the treatments applied promptly the decrease of both C:S and N:S ratios to 70 and 68\%, respectively. Nevertheless, eicosapentaenoic:arachidonic acid ratio increased with N:S treatments by three and a half fold. In Isochrysis sp., the elemental stoichiometry was constrained against treatments until the highest sulfur input. Overall, sulfur supply highlighted microalgae taxonomic differences and suggested that biochemical control is required, even in nutrient replete conditions, to fully exploit their potential as added value biomachineries.
\end{abstract}

Keywords Sulfur $\cdot$ Nannochloropsis gaditana $\cdot$ Rhodomonas marina $\cdot$ Isochrysis $\mathrm{sp}$.

\section{Introduction}

Microalgae are known for being primary sources of essential nutrients that display important functions in human metabolism (Koller et al. 2014). In this regard, polyunsaturated fatty acids (PUFA) are acknowledged for their structural and physiological roles (e.g., biosynthesis of eicosanoids) (Koller et al. 2014). Moreover, their implication on the mitigation of inflammatory processes, cardiovascular health, and cancer prevention makes these bioactive compounds suitable for therapeutic and pharmaceutical applications (Koller et al. 2014). In

Nereida Cordeiro

ncordeiro@staff.uma.pt

1 LB3, Faculty of Sciences and Engineering, University of Madeira, Campus Universitário da Penteada, 9020-105 Funchal, Portugal

2 Oceanic Observatory of Madeira, Agência Regional para o Desenvolvimento da Investigação Tecnologia e Inovação, 9020-105 Funchal, Portugal

3 Mariculture Center of Calheta, Vila da Calheta, 9370-133 Calheta, Madeira, Portugal

4 CIIMAR, Interdiciplinary Centre of Marine and Environmental Research, Rua dos Bragas 289, 4050-123 Porto, Portugal the aquaculture field microalgae are used to enhance fish lipids in PUFA (Koller et al. 2014). Therefore, their enhancement in PUFA, namely eicosapentaenoic acid (EPA$\mathrm{C} 20: 5 \omega 3)$ and docosahexaenoic acid (DHA-C22:6w3), is crucial for the use of microalgae for aquaculture purposes (Fidalgo et al. 1998; Koller et al. 2014). The eustigmatophyte Nannochloropsis gaditana, the cryptophyte Rhodomonas marina, and the prymnesophyte Isochrysis sp. are three marine microalgae commonly employed in aquaculture hatcheries as dietetic supply of essential nutrients.

The statement that microalgae nutritional value can be manipulated through changes in their growth conditions has been the focus of industrial and scientific developments (Fidalgo et al. 1998). Changes in growth media, namely in nutrient supply comprise a stress-inducement strategy often applied with the aim of optimizing microalgae composition for commercial and aquaculture purposes (Feng et al. 2011; Fields et al. 2014; Mayers et al. 2014). Nitrogen and sulfur are both macronutrients crucial for protein and vitamin biosynthesis and chlorophyll production, which are essential to meet growing cell requirements (Sukenik 1991; Irihimovitch and Yehudai-Resheff 2008; Giordano and Raven 2014). Thus the presence and concentration of these nutrients can influence the growth, biochemical composition and product yield of microalgae (Karemore et al. 2013).

When microalgae are exposed to changes in their growth conditions, they may respond in two ways: maintain the cell 
composition and functional activities at the expense of growth (homeostasis) or modulate their metabolic strategies and cell composition (acclimation) (Montechiaro et al. 2006). For instance, nutrient fluctuations may comprise alterations in their acquisition and metabolism leading to changes in microalgal elemental composition (Montechiaro et al. 2006). The way in which microalgae respond is linked with their metabolic regulation (Giordano and Raven 2014).

The acquisition and assimilation of nutrients by microalgal cells are dependent on nutrients concentration and balance with the other medium components (Giordano and Raven 2014; Mera et al. 2016). In the wide array of nutrients commonly used in microalgal culture media, sulfur seems to be the macronutrient less studied for its impacts in microalgae biochemical composition (Mera et al. 2016). With the knowledge that microalgae have different nutrient requirements, the aims of the present study were to investigate the effect of nitrogen and sulfur molar ratios on biochemical composition, growth, and elemental stoichiometry of $N$. gaditana, $R$. marina and Isochrysis sp. for aquaculture purposes.

\section{Materials and methods}

\section{Growth conditions and experimental design}

The eustigmatophyte Nannochloropsis gaditana, the cryptophyte Rhodomonas marina and the prymnesophyte Isochrysis sp. were obtained from the private collection of Mariculture Center of Calheta (Madeira, Portugal). The cultivation of each microalga was performed by inoculating starter cultures into $500 \mathrm{~mL}$ of enriched seawater. The initial cell density was $2.5 \times 10^{6}$ cells $\mathrm{mL}^{-1}$ for both $N$. gaditana and Isochrysis sp. assays, and $1.4 \times 10^{5}$ cells $\mathrm{mL}^{-1}$ for $R$. marina. The natural seawater used, for media preparation, was adjusted to a salinity of $25 \mathrm{~g} \mathrm{~L}^{-1}$ and sterilized by autoclaving (Uniclav 88) at $121{ }^{\circ} \mathrm{C}$ for $15 \mathrm{~min}$.

Nutribloom plus medium (Necton, Portugal) was used as the basal formula for the nutrient ratio manipulations (Table 1). The selection of this medium was related to its use in the Mariculture Center of Calheta for microalgal growth with aquaculture purposes. For the experiment the Nutribloom plus medium was modified with variable amounts of anhydrous $\mathrm{Na}_{2} \mathrm{SO}_{4}$ in order to reach the following $\mathrm{N}: \mathrm{S}$ ratios: 645:1 (NS), 189:1 (NS3), 110:1 (NS6). The final nutrient concentrations are displayed in Table 1. Temperature was kept at $23 \pm 1{ }^{\circ} \mathrm{C}$, the photoperiod at 18:6 h light/dark cycles, $\mathrm{pH}$ ranging $8 \pm 1$, light intensity at $52 \mu \mathrm{mol}$ photons $\mathrm{m}^{-2} \mathrm{~s}^{-1}$ and compressed air was used for the aeration of cell cultures.

The microalgae were harvested at stationary phase, centrifuged (Labofuge 200; Heraeus) for $5 \mathrm{~min}$ at $4500 \mathrm{rpm}$ and washed twice with distilled water. Growth was monitored daily with a Neubauer-improved counting chamber
Table 1 Composition of the standard Nutribloom plus culture medium with variable amounts of sodium sulfate

\begin{tabular}{|c|c|c|c|}
\hline \multirow[t]{2}{*}{ Component } & \multicolumn{3}{|c|}{ Concentration in final growth medium } \\
\hline & NS & NS3 & NS6 \\
\hline $\mathrm{NaNO}_{3}$ & $4 \mathrm{mM}$ & $4 \mathrm{mM}$ & $4 \mathrm{mM}$ \\
\hline $\mathrm{KH}_{2} \mathrm{PO}_{4}$ & $0.2 \mathrm{mM}$ & $0.2 \mathrm{mM}$ & $0.2 \mathrm{mM}$ \\
\hline EDTA & $0.05 \mathrm{mM}$ & $0.05 \mathrm{mM}$ & $0.05 \mathrm{mM}$ \\
\hline $\mathrm{FeCl}_{3} \cdot 6 \mathrm{H}_{2} \mathrm{O}$ & $0.04 \mathrm{mM}$ & $0.04 \mathrm{mM}$ & $0.04 \mathrm{mM}$ \\
\hline $\mathrm{ZnCl}_{2}$ & $2 \mu \mathrm{M}$ & $2 \mu \mathrm{M}$ & $2 \mu \mathrm{M}$ \\
\hline $\mathrm{ZnSO}_{4}$ & $2 \mu \mathrm{M}$ & $2 \mu \mathrm{M}$ & $2 \mu \mathrm{M}$ \\
\hline $\mathrm{MnCl}_{2} \cdot 2 \mathrm{H}_{2} \mathrm{O}$ & $2 \mu \mathrm{M}$ & $2 \mu \mathrm{M}$ & $2 \mu \mathrm{M}$ \\
\hline $\mathrm{Na}_{2} \mathrm{MoO}_{4} \cdot 2 \mathrm{H}_{2} \mathrm{O}$ & $0.2 \mu \mathrm{M}$ & $0.2 \mu \mathrm{M}$ & $0.2 \mu \mathrm{M}$ \\
\hline $\mathrm{CoCl}_{2} \cdot 6 \mathrm{H} 2 \mathrm{O}$ & $0.2 \mu \mathrm{M}$ & $0.2 \mu \mathrm{M}$ & $0.2 \mu \mathrm{M}$ \\
\hline $\mathrm{CuSO}_{4} \cdot 5 \mathrm{H}_{2} \mathrm{O}$ & $0.2 \mu \mathrm{M}$ & $0.2 \mu \mathrm{M}$ & $0.2 \mu \mathrm{M}$ \\
\hline $\mathrm{MgSO}_{4} \cdot 7 \mathrm{H}_{2} \mathrm{O}$ & $4 \mu \mathrm{M}$ & $4 \mu \mathrm{M}$ & $4 \mu \mathrm{M}$ \\
\hline $\mathrm{Na}_{2} \mathrm{SO}_{4}$ & - & $15 \mu \mathrm{M}$ & $30 \mu \mathrm{M}$ \\
\hline \multicolumn{4}{|l|}{ Vitamins $\left(\mathrm{mg} \mathrm{L}^{-1}\right)$} \\
\hline Tiamine & 0.07 & 0.07 & 0.07 \\
\hline Biotin & 0.01 & 0.01 & 0.01 \\
\hline $\mathrm{B}_{12}$ & 0.006 & 0.006 & 0.006 \\
\hline
\end{tabular}

(Marienfield-Superior) and a light microscope (Olympus BX41) at $\times 400$ magnification.

\section{Biochemical composition}

Determination of CHNS content was made by an elemental analyzer Truspec 630-200-200. Total protein was assessed by multiplying the nitrogen content for 6.25 as described by Kim et al. (2014). Total lipids determination was performed according to the modified Bligh and Dyer (1959) method. Briefly, to the freeze-dried algal biomass was added $3 \mathrm{~mL}$ of a methanol:chloroform mixture $(2: 1 \mathrm{v} / \mathrm{v})$ followed by $400 \mu \mathrm{L}$ of a saturated solution of $\mathrm{KCl}$ and $2 \mathrm{~mL}$ of chloroform. After homogenization, $2 \mathrm{~mL}$ of distilled water was added and the mixture was left stirring for $15 \mathrm{~min}$. Then the sample was allowed to settle and the organic phase was removed by pipetting. Finally, the solvent was evaporated in a Büchi rotavapor R-200 in order to proceed to lipids gravimetric quantification. Lipid and protein contents are presented relative to the dry biomass weight (DW).

\section{Fatty acid determination}

The fatty acid composition of algal dried biomass was determined as fatty acid methyl esters (FAME) as previously described by Lepage and Roy (1986), modified by Cohen et al. (1988). FAME were analyzed by gas chromatography (Agilent HP 6890) equipped with a mass selective detector (Agilent 5973) and a fused silica capillary column DB-5MS 
Fig. 1 Growth curves for a $N$. gaditana, b R. marina, and $\mathbf{c}$ Isochrysis sp. in treatments NS, NS3, and NS6 a)

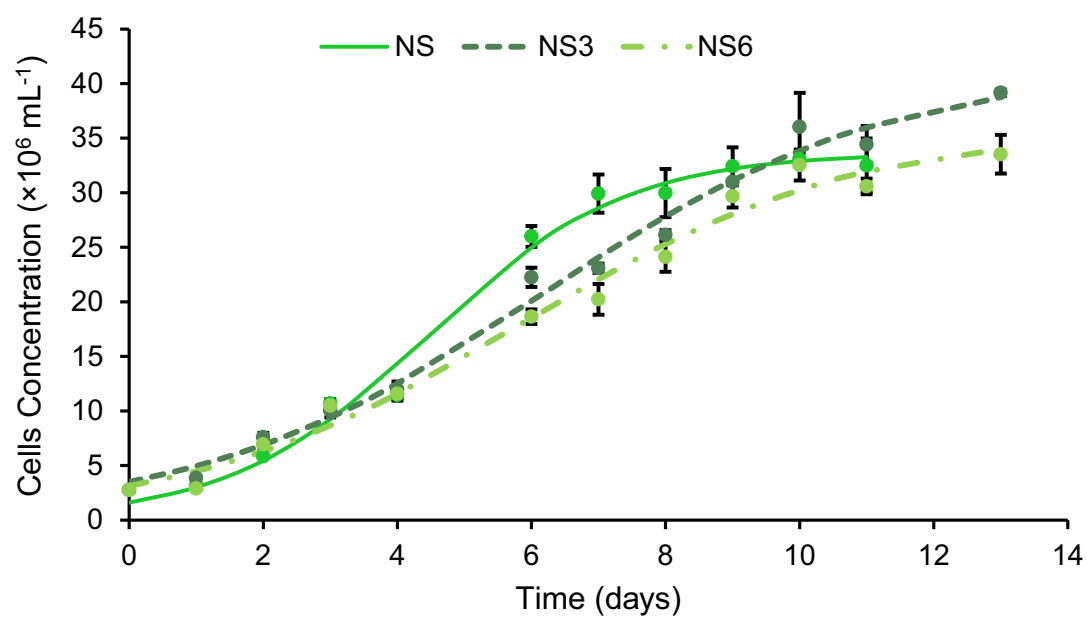

b)

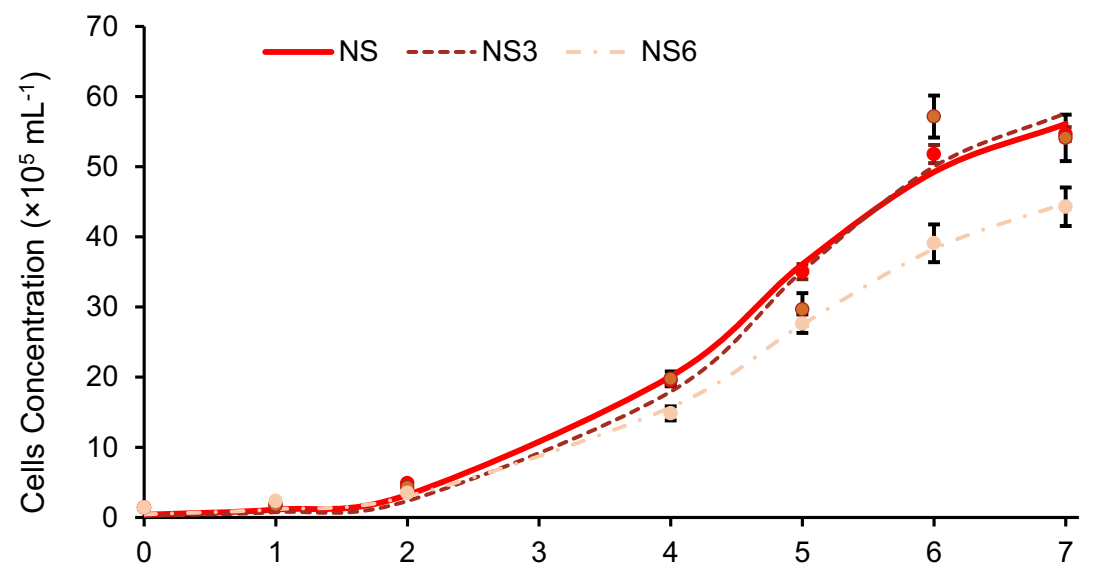

c)

Time (days)

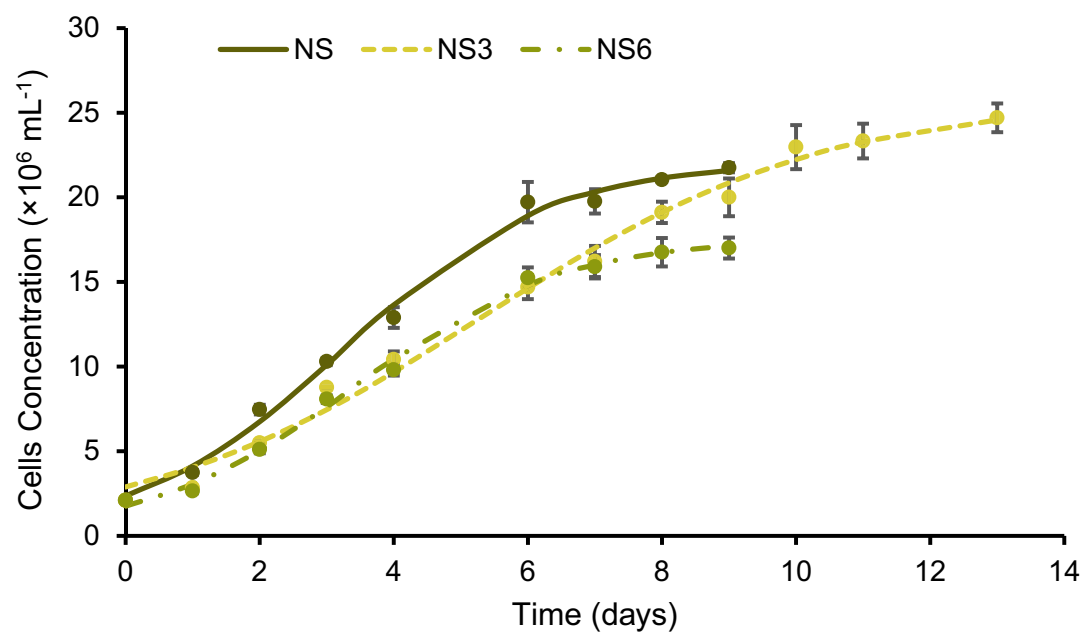


(30 $\mathrm{m} \times 0.25 \mathrm{~mm}$ inner diameter, $0.25 \mu \mathrm{m}$ film thickness) from J\&W Scientific. The chromatographic conditions were as follows: oven initial temperature was $150{ }^{\circ} \mathrm{C}$ for $2 \mathrm{~min}$; increasing $3{ }^{\circ} \mathrm{C} \mathrm{min}{ }^{-1}$ to $205{ }^{\circ} \mathrm{C}$ and kept for $2 \min , 3{ }^{\circ} \mathrm{C}$ $\min ^{-1}$ to $230{ }^{\circ} \mathrm{C}$ and $30{ }^{\circ} \mathrm{C} \mathrm{min}{ }^{-1}$ until reaching the final temperature of $300{ }^{\circ} \mathrm{C}$ for $5 \mathrm{~min}$; transfer line temperature $260{ }^{\circ} \mathrm{C}$; detector temperature, $270{ }^{\circ} \mathrm{C}$; split ratio, 40:1. Helium was used as the carrier gas with a flow rate of $1 \mathrm{~mL}$ $\mathrm{min}^{-1}$. The FAME identification was accomplished by comparing the retention times and mass spectra fragmentation to those of known standards (bacterial acid methyl esters CP mix and Supelco 37 component FAME mix from Supelco). Four replicates were performed for each $\mathrm{GC}$ analysis with the results presented as the mean value \pm standard deviation (SD) of FAME expressed in $\mathrm{mg} \mathrm{g}^{-1} \mathrm{DW}$. The internal standard used was heneicosanoic acid (C21:0).

\section{Statistical analysis}

In algal growth curves, non-linear regression trend lines were fit to data with Excel Solver Add In. Statistical analysis of the data was carried out using the software IBM SPSS Statistics 23. Differences between nutrient availability treatments were assessed by one-way analysis of variance (ANOVA) followed by a Tukey's post hoc analysis; $p$ values $<0.05$ were considered to be statistically significant.

\section{Results and discussion}

\section{Growth and biochemical composition}

The productivity of microalgae is dependent on factors such as cell concentrations, carbon fixation efficiency, and conversion of photosynthate into the desired products (Ho et al. 2003; Andersen 2013). Since nitrogen and sulfur are involved as catalyst components in the downstream cellular processes that lead to fatty acid synthesis, the manipulation of their availabilities on growth medium can trigger changes on growth rate, protein, and lipid levels (Bell et al. 2003; Giordano and Raven 2014). Table 1 displays the microalgae growth rate, total lipids, total proteins, and elemental composition according to the different nitrogen and sulfur ratios in the growth medium.

The growth curves for the marine microalgae at different $\mathrm{N}: \mathrm{S}$ ratios are displayed in Fig. 1. Through this figure, it is possible to visualize that, for $N$. gaditana (Fig. 1a) and Isochrysis sp. (Fig. 1c), the $\mathrm{N}: \mathrm{S}$ ratios influenced the time that microalgae needed to reach the stationary phase. This was also reflected in the maximum cell density achieved by these microalgae $36.54 \times 10^{6} \mathrm{~mL}^{-1}$ and $23.66 \times 10^{6}$ cells $\mathrm{mL}^{-1}$ at NS3 treatment for $N$. gaditana and Isochrysis sp., respectively.

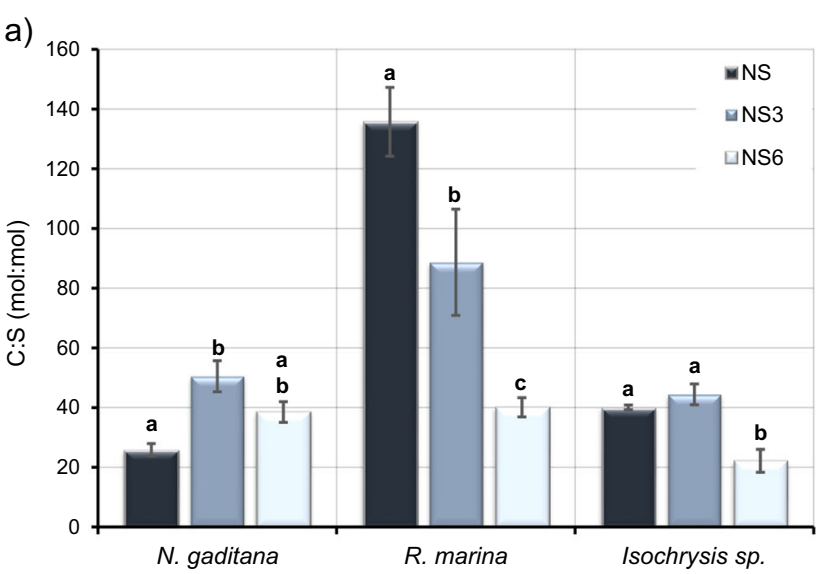

b)

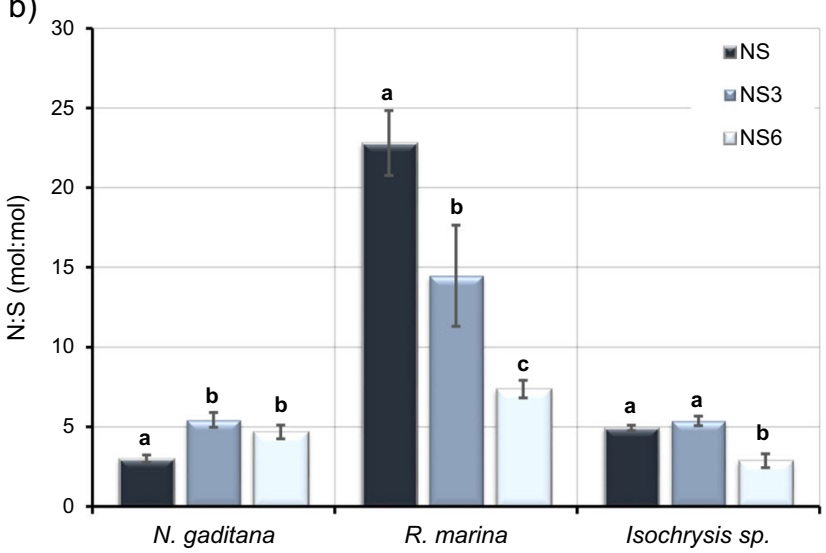

c)

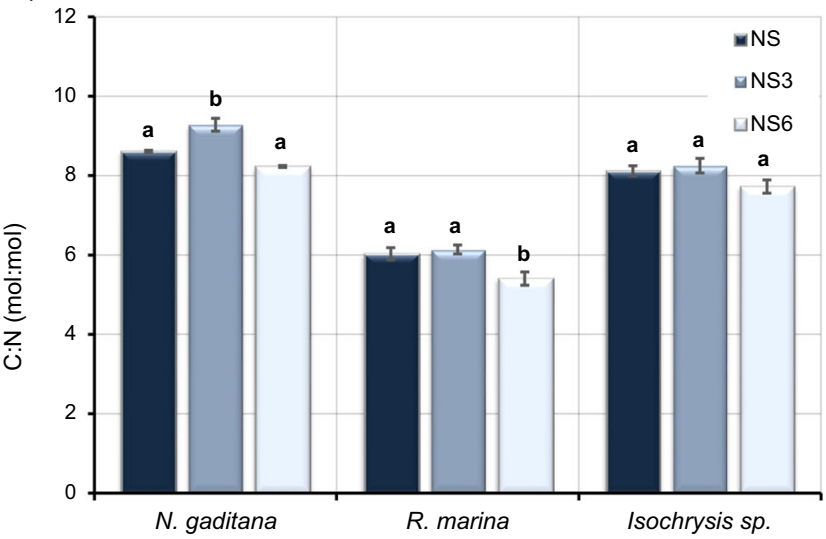

Fig. 2 Microalgae molar stoichiometry variation with $\mathrm{N}$ : $\mathrm{S}$ ratios: a carbon: sulfur $(\mathrm{C}: \mathrm{S})$; b nitrogen: sulfur $(\mathrm{N}: \mathrm{S})$, and c carbon: nitrogen $(\mathrm{C}: \mathrm{N})$ Values (means $\pm \mathrm{SD}$ ) in the same microalgae not sharing a common superscript are significantly different $(\mathrm{p}<0.05)$

In both R. marina and Isochrysis sp. cultures, the cell growth rate decreased along with the protein content upon treatments (Table 1). These results might be explained by the crucial role of proteins to sustain growth, which, in turn, is dependent on the nitrogen level (Andersen 2013). When the nitrogen level is below from that required for protein biosynthesis, the growth of microalgae can be affected. Moreover, as with nutrient depletion, nutrient oversupply (sulfur) can also promote stress. 
Table 2 Microalgae maximum cell concentration and biochemical parameters against sulfur supply treatments

\begin{tabular}{|c|c|c|c|c|}
\hline \multirow[t]{2}{*}{ Parameter } & \multirow[t]{2}{*}{ Microalgae } & \multicolumn{3}{|l|}{ Treatments } \\
\hline & & NS & NS3 & NS6 \\
\hline \multirow[t]{3}{*}{$\mu\left(d^{-1}\right)$} & $N$. gaditana & $0.69 \pm 0.02^{\mathrm{a}}$ & $0.44 \pm 0.03^{\mathrm{b}}$ & $0.47 \pm 0.00^{\mathrm{b}}$ \\
\hline & R. marina & $1.11 \pm 0.11^{\mathrm{a}}$ & $1.02 \pm 0.06^{\mathrm{b}}$ & $0.97 \pm 0.01^{\mathrm{b}}$ \\
\hline & Isochrysis sp. & $0.63 \pm 0.01^{\mathrm{a}}$ & $0.47 \pm 0.06^{\mathrm{a}}$ & $0.55 \pm 0.07^{\mathrm{a}}$ \\
\hline \multicolumn{5}{|c|}{ Elemental composition } \\
\hline \multirow[t]{3}{*}{$\mathrm{C}(\% \mathrm{DW})$} & N. gaditana & $12.51 \pm 1.04^{\mathrm{a}}$ & $20.95 \pm 1.94^{\mathrm{b}}$ & $17.39 \pm 0.81^{\mathrm{ab}}$ \\
\hline & R. marina & $28.87 \pm 0.60^{\mathrm{a}}$ & $29.65 \pm 2.25^{\mathrm{a}}$ & $21.64 \pm 0.61^{\mathrm{a}}$ \\
\hline & Isochrysis sp. & $19.60 \pm 1.17^{\mathrm{a}}$ & $21.56 \pm 2.03^{\mathrm{a}}$ & $12.51 \pm 0.38^{\mathrm{b}}$ \\
\hline \multirow[t]{3}{*}{$\mathrm{N}(\% \mathrm{DW})$} & $N$. gaditana & $1.69 \pm 0.15^{\mathrm{a}}$ & $2.63 \pm 0.20^{\mathrm{b}}$ & $2.46 \pm 0.12^{\mathrm{b}}$ \\
\hline & R. marina & $5.59 \pm 0.07^{\mathrm{a}}$ & $5.63 \pm 0.32^{\mathrm{a}}$ & $4.67 \pm 0.06^{\mathrm{a}}$ \\
\hline & Isochrysis sp. & $2.81 \pm 0.12^{\mathrm{a}}$ & $3.05 \pm 0.22^{\mathrm{a}}$ & $1.89 \pm 0.02^{\mathrm{b}}$ \\
\hline \multirow[t]{3}{*}{$\mathrm{S}(\% \mathrm{DW})$} & $N$. gaditana & $1.30 \pm 0.21^{\mathrm{a}}$ & $1.11 \pm 0.01^{\mathrm{a}}$ & $1.21 \pm 0.05^{\mathrm{a}}$ \\
\hline & R. marina & $0.57 \pm 0.05^{\mathrm{a}}$ & $0.92 \pm 0.25^{\mathrm{a}}$ & $1.45 \pm 0.10^{\mathrm{b}}$ \\
\hline & Isochrysis sp. & $1.31 \pm 0.10^{\mathrm{a}}$ & $1.30 \pm 0.02^{\mathrm{a}}$ & $1.52 \pm 0.22^{\mathrm{a}}$ \\
\hline \multicolumn{5}{|c|}{ Proximal composition } \\
\hline \multirow[t]{3}{*}{ Lipid (\% DW) } & N. gaditana & $4.27 \pm 0.38^{\mathrm{a}}$ & $7.11 \pm 0.12^{\mathrm{b}}$ & $6.79 \pm 0.11^{\mathrm{b}}$ \\
\hline & R. marina & $12.09 \pm 0.31^{\mathrm{a}}$ & $15.02 \pm 0.41^{\mathrm{b}}$ & $11.79 \pm 0.44^{\mathrm{a}}$ \\
\hline & Isochrysis sp. & $13.48 \pm 0.02^{\mathrm{a}}$ & $15.52 \pm 0.42^{\mathrm{b}}$ & $10.44 \pm 0.37^{\mathrm{c}}$ \\
\hline \multirow[t]{3}{*}{ Protein (\% DW) } & N. gaditana & $10.58 \pm 0.91^{\mathrm{a}}$ & $16.44 \pm 1.24^{\mathrm{b}}$ & $15.40 \pm 0.76^{\mathrm{b}}$ \\
\hline & R. marina & $34.91 \pm 0.42^{\mathrm{a}}$ & $35.18 \pm 2.02^{\mathrm{a}}$ & $29.17 \pm 0.40^{\mathrm{b}}$ \\
\hline & Isochrysis $\mathrm{sp}$. & $17.58 \pm 0.77^{\mathrm{a}}$ & $19.03 \pm 1.37^{\mathrm{a}}$ & $11.80 \pm 0.11^{\mathrm{b}}$ \\
\hline \multirow[t]{3}{*}{$\mathrm{L} / \mathrm{P}(\mathrm{W}: \mathrm{W} \%)$} & $N$. gaditana & $0.41 \pm 0.07^{\mathrm{a}}$ & $0.43 \pm 0.04^{\mathrm{a}}$ & $0.44 \pm 0.01^{\mathrm{a}}$ \\
\hline & R. marina & $0.35 \pm 0.00^{\mathrm{a}}$ & $0.43 \pm 0.01^{\mathrm{ab}}$ & $0.4 \pm 0.02^{\mathrm{b}}$ \\
\hline & Isochrysis sp. & $0.77 \pm 0.03^{\mathrm{a}}$ & $0.82 \pm 0.08^{\mathrm{a}}$ & $0.88 \pm 0.04^{\mathrm{a}}$ \\
\hline
\end{tabular}

Values (means $\pm \mathrm{SD}$ ) in the same row not sharing a common superscript are significantly different $(p<0.05)$

DW, dry weight

In $N$. gaditana, significant differences $(p<0.05)$ were observed in the relative amount of lipids and proteins upon the treatments applied (Table 1). These differences indicate that treatments with low N:S ratios, NS3 and NS6, had a positive influence on the lipid and protein contents increasing up to 67 and $55 \%$, respectively, suggesting that the content of these two macromolecular pools were dependent on the nutrient balance in the medium. High lipid contents are often associated with lower growth rates in microalgae (Fernandes et al. 2016); this was observed in N. gaditana with the NS3 and NS6 treatments having the lowest growth rates.

Changes in the uptake rates of the chemical elements may lead to repercussions in cell stoichiometry and, consequently, in the organic composition of cells as well as in the size of metabolic pools (protein, lipid, and carbohydrate) (Giordano 2013). The uptake of the essential nutrients from the external environment by microalgal cells depends on several parameters such as nutrient bioavailability, concentration, and ratio with the other nutrients present in the growth medium among others (Ho et al. 2003).
The molar stoichiometry of microalgae presented significant differences $(p<0.05)$ with respect to the treatments applied. In N. gaditana, treatments NS3 and NS6 lead to an increase in nitrogen and carbon contents evidenced by a rise in carbon: sulfur (C:S) (Fig. 2a) and nitrogen: sulfur (N:S) ratios (Fig. 2b) up to $95 \%$ and $81 \%$, respectively. In $R$. marina, the same treatments prompt the decrease of both $\mathrm{C}: \mathrm{S}$ and $\mathrm{N}: \mathrm{S}$ down to $70 \%$ and $68 \%$, respectively. With respect to Isochrysis sp., only the NS6 treatment led to low C:S (22.19) and N:S (2.87) ratios, suggesting that at this point the concentration of sulfur in the growth medium negatively influenced carbon and nitrogen acquisition.

Microalgae are adapted to scavenge their environments for resources. In the presence of an increasing perturbation such as alterations in nutrient ratios, microalgae cells react by adjusting the capacity, resource utilization, and flux rates in order to readily adapt and tolerate stress input. The way by which microalgae respond to deviations from normal operating conditions is species-specific. Nannochloropsis gaditana 
Table $3 N$. gaditana fatty acid profile under different N:S ratios in growth media

\begin{tabular}{|c|c|c|c|}
\hline \multirow{2}{*}{$\begin{array}{l}\text { Fatty acids } \\
\left(\mathrm{mg} \mathrm{g}^{-1} \mathrm{DW}\right)\end{array}$} & \multicolumn{3}{|l|}{ Treatment } \\
\hline & NS & NS3 & NS6 \\
\hline C14:00 & $0.29 \pm 0.02^{\mathrm{a}}$ & $0.41 \pm 0.01^{\mathrm{b}}$ & $0.28 \pm 0.04^{\mathrm{a}}$ \\
\hline C16:00 & $4.54 \pm 0.21^{\mathrm{a}}$ & $6.36 \pm 0.13^{\mathrm{b}}$ & $5.07 \pm 0.27^{\mathrm{c}}$ \\
\hline C18:00 & $0.16 \pm 0.00^{\mathrm{a}}$ & $0.22 \pm 0.00^{\mathrm{b}}$ & $0.16 \pm 0.01^{\mathrm{a}}$ \\
\hline Total-SFA $^{1}$ & $5.45 \pm 0.24^{\mathrm{a}}$ & $7.74 \pm 0.15^{\mathrm{b}}$ & $6.07 \pm 0.31^{\mathrm{c}}$ \\
\hline $\mathrm{C} 16: 1$ & $1.08 \pm 0.04^{\mathrm{a}}$ & $1.52 \pm 0.05^{\mathrm{b}}$ & $1.43 \pm 0.19^{\mathrm{b}}$ \\
\hline $\mathrm{C} 18: 1$ & $1.62 \pm 0.09^{\mathrm{a}}$ & $2.24 \pm 0.14^{\mathrm{b}}$ & $1.58 \pm 0.15^{\mathrm{a}}$ \\
\hline Total-MUFA $^{1}$ & $2.84 \pm 0.12^{\mathrm{a}}$ & $3.95 \pm 0.16^{\mathrm{b}}$ & $3.15 \pm 0.14^{\mathrm{c}}$ \\
\hline $\mathrm{C} 16: 3 \oplus 3$ & $1.58 \pm 0.07^{\mathrm{a}}$ & $1.48 \pm 0.03^{\mathrm{a}}$ & $1.40 \pm 0.17^{\mathrm{a}}$ \\
\hline $\mathrm{C} 18: 2 \oplus 6$ & $2.76 \pm 0.11^{\mathrm{a}}$ & $4.27 \pm 0.07^{\mathrm{b}}$ & $3.22 \pm 0.25^{\mathrm{c}}$ \\
\hline $\mathrm{C} 18: 3 \oplus 3$ & $4.66 \pm 0.23^{\mathrm{a}}$ & $4.85 \pm 0.21^{\mathrm{a}}$ & $4.15 \pm 0.35^{\mathrm{a}}$ \\
\hline $\mathrm{C} 18: 4 \oplus 3$ & $0.28 \pm 0.01^{\mathrm{a}}$ & $0.25 \pm 0.01^{\mathrm{b}}$ & $0.31 \pm 0.00^{\mathrm{c}}$ \\
\hline $\mathrm{C} 20: 3 \oplus 6$ & $0.08 \pm 0.00^{\mathrm{a}}$ & $0.16 \pm 0.00^{\mathrm{b}}$ & $0.12 \pm 0.02^{\mathrm{c}}$ \\
\hline C20:4ø6-AA & $0.07 \pm 0.00^{\mathrm{a}}$ & $0.15 \pm 0.00^{\mathrm{b}}$ & $0.11 \pm 0.02^{\mathrm{c}}$ \\
\hline C20:5ळ3-EPA & $1.09 \pm 0.02^{\mathrm{a}}$ & $1.35 \pm 0.02^{\mathrm{b}}$ & $1.11 \pm 0.03^{\mathrm{a}}$ \\
\hline Total-PUFA $^{1}$ & $11.71 \pm 0.41^{\mathrm{a}}$ & $14.29 \pm 0.26^{\mathrm{b}}$ & $11.88 \pm 0.37^{\mathrm{a}}$ \\
\hline$\sum \oplus 3$ & $7.90 \pm 0.28^{\mathrm{a}}$ & $8.28 \pm 0.21^{\mathrm{b}}$ & $7.18 \pm 0.58^{\mathrm{a}}$ \\
\hline$\sum \omega 6$ & $2.97 \pm 0.12^{\mathrm{a}}$ & $4.70 \pm 0.07^{\mathrm{b}}$ & $3.51 \pm 0.29^{\mathrm{c}}$ \\
\hline$\sum \oplus 3: \sum \omega 6$ & $2.66 \pm 0.07^{\mathrm{a}}$ & $1.76 \pm 0.04^{\mathrm{b}}$ & $2.06 \pm 0.34^{\mathrm{b}}$ \\
\hline ๑3 HUFA & $1.38 \pm 0.02^{\mathrm{a}}$ & $1.69 \pm 0.02^{\mathrm{b}}$ & $1.32 \pm 0.07^{\mathrm{a}}$ \\
\hline EPA:AA & $15.59 \pm 0.79^{\mathrm{a}}$ & $8.80 \pm 0.09^{\mathrm{b}}$ & $10.45 \pm 2.96^{\mathrm{b}}$ \\
\hline (SFA + MUFA):PUFA & $0.71 \pm 0.02^{\mathrm{a}}$ & $0.82 \pm 0.02^{\mathrm{b}}$ & $0.78 \pm 0.03^{\mathrm{b}}$ \\
\hline Total $^{1}$ & $20.00 \pm 0.74^{\mathrm{a}}$ & $25.98 \pm 0.47^{\mathrm{b}}$ & $21.10 \pm 0.72^{\mathrm{a}}$ \\
\hline
\end{tabular}

Values (means $\pm \mathrm{SD}$ of four replications) in the same row not sharing a common superscript are significantly different $(p<0.05)$

${ }^{1}$ Contains some minor components not shown

${ }^{2}$ Contains $\omega 9$ and $\omega 7$ isomers

SFA, saturated fatty acid; MUFA, monounsaturated fatty acid; PUFA, polyunsaturated fatty acid; $L C-P U F A$, long-chain polyunsaturated fatty acid; $D W$, dry weight

responded to increased sulfur inputs by increasing and/or adjusting the flux rates toward the acquisition of the limiting nutrients (carbon and nitrogen), while R. marina responded to sulfur supply by enhancing its acquisition, and finally, Isochrysis sp. by maintaining cells stoichiometric balance (homeostasis), until the sulfur input seemed to have exceeded the threshold concentration.

Elemental C:N ratios (Fig. 2c) are often linked to the flux balance between carbohydrate, lipid, and protein pools (Palmucci et al. 2011; Fernandes et al. 2016). Thus carbohydrate and lipids are known for being the major carbon molecular pools, whereas proteins are the major route for nitrogen assimilation (Palmucci et al. 2011). In $N$. gaditana, significant differences $(p<0.05)$ in the $\mathrm{C}: \mathrm{N}$ ratio, along with a steady L:P ratio, were observed in microalgae subjected to treatment NS3 (Table 2). Thus, the increase in $N$. gaditana $\mathrm{C}: \mathrm{N}$ ratio (Fig. 2c) may indicate that this treatment resulted in a larger allocation of carbon in carbohydrates since the ratio L:P remained constant (Table 2). In $R$. marina, the decrease in $\mathrm{C}: \mathrm{N}$ ratio, observed for the microalgae grown in the highest sulfur supply (NS6), was coupled with an increase in the L:P ratio $(14 \%)$. Having into account the relationship between the elemental C:N ratio and the main macromolecular pools, this might be explained by the decrease of carbohydrates in regard to protein which may lead to an increase in C:N ratio. In Isochrysis sp., both the C:N and the L:P ratios presented no significant differences $(p<0.05)$ indicating that this microalga responded to sulfur supply by constraining the $\mathrm{C}: \mathrm{N}$ ratio and maintaining cell homeostasis.

\section{Fatty acid content}

Fatty acid biosynthesis requires several steps that are restricted by enzymes such as thioesterases, elongases, acyl-coenzyme A (acyl-CoA) synthetases, and acyltransferases, and by the supply of energy and precursors (Muhlroth et al. 2013). Throughout these steps, sulfur is underlined as a key component in prosthetic groups (e.g., phosphopantetheine) and enzyme cofactors (e.g., coenzyme A (CoA)) (Muhlroth et al. 2013).

Table 3 displays the fatty acid profile pattern for $N$. gaditana subjected to treatments with different molar $\mathrm{N}: \mathrm{S}$ ratios in the growth medium. The amount of individual fatty acids showed significant differences $(p<0.05)$ between the treatments applied. The major fatty acids were palmitic acid (C16:0) and alpha-linolenic acid (ALA, C18:3w3), which together accounted for over $40 \%$ of total fatty acids detected. In this microalga, treatments NS3 and NS6 lead to an increase in all fatty acid sets, namely in saturated fatty acids (SFA) and monounsaturated fatty acids (MUFA), up to 42 and 39\%, respectively.

In treatments NS3 and NS6, the changes in the medium prompted an increase in C16:0, monounsaturated stearic acid (C18:1) and linoleic acid (LA, C18:2w6) contents (Table 3). C16:0 and C18:1 are both products of plastidial de novo FA synthesis and can be further synthesized into PUFA in the endoplasmic reticulum (Chen et al. 2013; Huerlimann et al. 2014). Thus, their enhancement along with polyunsaturated fatty acids (PUFAs) can be explained by increased plastidial production, possibly induced by the treatment with the $\mathrm{N}: \mathrm{S}=$ 189:1 ratio, NS3.

The conversion of arachidonic acid (AA, C20:4ø3) to eicosapentaenoic acid (EPA, C20:5@3) catalyzed by the omega $3(\curvearrowleft 3)$ desaturase is the main route of EPA biosynthesis in Nannochloropsis (Stefels 2000; Rocha et al. 2003; Harwood and Guschina 2009). Sulfur supply triggered omega 6 (ळ6) fatty acids accumulation, namely the precursor of the $₫ 6 \mathrm{LC}$ PUFA, this increase converged in an increased EPA content (Table 3). 
Table $4 \quad$ R. marina fatty acid profile under different N:S ratios in the growth media

\begin{tabular}{|c|c|c|c|}
\hline \multirow[t]{2}{*}{ Fatty Acids ( $\left.\mathrm{mg} \mathrm{g}^{-1} \mathrm{DW}\right)$} & \multicolumn{3}{|l|}{ Treatment } \\
\hline & NS & NS3 & NS6 \\
\hline C14:0 & $2.97 \pm 0.19^{\mathrm{a}}$ & $3.15 \pm 0.13^{\mathrm{a}}$ & $1.87 \pm 0.06^{\mathrm{b}}$ \\
\hline $\mathrm{C} 16: 0$ & $4.03 \pm 0.27^{\mathrm{a}}$ & $4.22 \pm 0.16^{\mathrm{a}}$ & $2.49 \pm 0.05^{\mathrm{b}}$ \\
\hline $\mathrm{C} 18: 0$ & $0.48 \pm 0.04^{\mathrm{a}}$ & $0.59 \pm 0.01^{\mathrm{b}}$ & $0.27 \pm 0.02^{\mathrm{c}}$ \\
\hline Total-SFA ${ }^{1}$ & $7.54 \pm 0.49^{\mathrm{a}}$ & $8.05 \pm 0.30^{\mathrm{a}}$ & $4.66 \pm 0.11^{\mathrm{b}}$ \\
\hline C16:1 & $0.97 \pm 0.15^{\mathrm{a}}$ & $0.67 \pm 0.02^{\mathrm{b}}$ & $0.77 \pm 0.05^{\mathrm{b}}$ \\
\hline C18:1 & $4.12 \pm 0.27^{\mathrm{a}}$ & $4.38 \pm 0.11^{\mathrm{a}}$ & $2.11 \pm 0.07^{\mathrm{b}}$ \\
\hline Total-MUFA $^{1}$ & $5.09 \pm 0.42^{\mathrm{a}}$ & $5.05 \pm 0.12^{\mathrm{a}}$ & $2.87 \pm 0.10^{\mathrm{b}}$ \\
\hline $\mathrm{C} 18: 2 \oplus 6$ & $7.10 \pm 0.46^{\mathrm{a}}$ & $9.34 \pm 0.22^{\mathrm{b}}$ & $3.79 \pm 0.05^{\mathrm{c}}$ \\
\hline $\mathrm{C} 18: 3 \oplus 3$ & $20.41 \pm 1.13^{\mathrm{a}}$ & $19.32 \pm 0.41^{\mathrm{a}}$ & $14.10 \pm 0.25^{\mathrm{b}}$ \\
\hline $\mathrm{C} 18: 4 \oplus 3$ & $18.46 \pm 1.03^{\mathrm{a}}$ & $17.12 \pm 0.30^{\mathrm{a}}$ & $15.49 \pm 0.22^{\mathrm{b}}$ \\
\hline C20:4ø6-AA & $0.19 \pm 0.02^{\mathrm{a}}$ & $0.25 \pm 0.03^{\mathrm{a}}$ & $0.03 \pm 0.00^{\mathrm{b}}$ \\
\hline C20:5ळ3-EPA & $12.10 \pm 0.53^{\mathrm{a}}$ & $10.12 \pm 0.05^{\mathrm{b}}$ & $7.33 \pm 0.09^{c}$ \\
\hline C22:6œ3-DHA & $8.34 \pm 0.54^{\mathrm{a}}$ & $7.89 \pm 0.24^{\mathrm{a}}$ & $5.15 \pm 0.15^{\mathrm{b}}$ \\
\hline Total-PUFA $^{1}$ & $66.89 \pm 3.62^{\mathrm{a}}$ & $64.51 \pm 0.73^{\mathrm{a}}$ & $46.06 \pm 0.51^{\mathrm{b}}$ \\
\hline$\sum \oplus 3$ & $59.31 \pm 3.13^{\mathrm{a}}$ & $54.45 \pm 0.58^{\mathrm{b}}$ & $42.07 \pm 0.47^{\mathrm{c}}$ \\
\hline$\sum \omega 6$ & $7.57 \pm 0.49^{\mathrm{a}}$ & $10.07 \pm 0.20^{\mathrm{b}}$ & $3.99 \pm 0.06^{\mathrm{c}}$ \\
\hline$\sum \oplus 3: \Sigma \oplus 6$ & $7.84 \pm 0.09^{\mathrm{a}}$ & $5.41 \pm 0.08^{\mathrm{b}}$ & $10.55 \pm 0.09^{\mathrm{c}}$ \\
\hline$\sum \oplus 3$ HUFA & $20.44 \pm 1.07^{\mathrm{a}}$ & $18.01 \pm 0.26^{\mathrm{b}}$ & $12.48 \pm 0.24^{\mathrm{c}}$ \\
\hline DHA:EPA & $0.69 \pm 0.02^{\mathrm{a}}$ & $0.78 \pm 0.02^{\mathrm{b}}$ & $0.70 \pm 0.01^{\mathrm{a}}$ \\
\hline EPA:AA & $64.42 \pm 6.26^{\mathrm{a}}$ & $40.14 \pm 4.13^{\mathrm{a}}$ & $229.31 \pm 30.09^{\mathrm{b}}$ \\
\hline (SFA + MUFA):PUFA & $0.19 \pm 0.00^{\mathrm{a}}$ & $0.20 \pm 0.00^{\mathrm{b}}$ & $0.16 \pm 0.00^{\mathrm{c}}$ \\
\hline Total $^{1}$ & $79.52 \pm 4.50^{\mathrm{a}}$ & $77.61 \pm 1.10^{\mathrm{a}}$ & $53.59 \pm 0.70^{\mathrm{b}}$ \\
\hline
\end{tabular}

Values (means \pm SD of four replications) in the same row not sharing a common superscript are significantly different $(p<0.05)$

${ }^{1}$ Contains some minor components not shown

${ }^{2}$ Contains $\omega 9$ and $\omega 7$ isomers

$S F A$, saturated fatty acid; $M U F A$, monounsaturated fatty acid; $P U F A$, polyunsaturated fatty acid; $L C-P U F A$, long-chain polyunsaturated fatty acid; $D W$, dry weight

Sulfur availability is known to influence photosynthesis efficiency and hence carbon assimilation and allocation (Simionato et al. 2013). According to Mizuno et al. (2013), sulfur decrease leads to an increase in starch and lipid contents along with changes in the fatty acid composition of Chlorella lobophora and Parachlorella kessleri. However, these changes involve an increase in C16:0 and C18:0 coupled with a decrease in PUFAs (Mizuno et al. 2013). In opposition to sulfur depletion conditions that induce a rapid decrease in photosynthesis efficiency, in sulfur replete media, the chloroplast transcriptional activity proceeds normally and results in PUFAs increase (Irihimovitch and Yehudai-Resheff 2008).

The general fatty acid profile of $R$. marina presented a similar trend across treatments, but evidencing some quantitative differences $(p<0.05)$ between media (Table 4$)$. ALA, stearidonic acid (SDA, C18:4w3), EPA, and DHA were the main fatty acids accounting together for over $65 \%$ of total fatty acids.
Furthermore, the fatty acid patterns suggest that R. marina responded to treatments NS3 and NS6 by changing the nutritional ratios that determine its applicability. For instance, the EPA:AA ratio increased by three and a half fold in microalgae subjected to the treatment NS6. EPA enrichment of live feeds is needed in marine hatcheries, making this microalgal species a suitable resource for aquaculture (Karlsen et al. 2015).

In R. marina, the increased sulfur uptake did not result in the enhancement of microalgae biochemical composition. This might indicate that: (i) the sulfur assimilation was diverted toward other sulfur-containing compounds such as low molecular weight compounds or sulfate esters, like carbohydrates; (ii) the amino acids composition may have shift toward sulfur-containing amino acids, despite no positive effects detected in protein content; and/or (iii) the excess sulfur was not assimilated.

The fatty acid profile of Isochrysis sp. showed significant differences in the relative amounts of fatty acids detected 
Table 5 Isochrysis $\mathrm{sp}$. fatty acid profile under different $\mathrm{N}: \mathrm{S}$ ratios in growth media

\begin{tabular}{|c|c|c|c|}
\hline \multirow{2}{*}{$\begin{array}{l}\text { Fatty acids } \\
\left(\mathrm{mg} \mathrm{g}^{-1} \mathrm{DW}\right)\end{array}$} & \multicolumn{3}{|l|}{ Treatment } \\
\hline & NS & NS3 & NS6 \\
\hline $\mathrm{C} 14: 0$ & $8.31 \pm 0.36^{\mathrm{a}}$ & $7.56 \pm 0.16^{\mathrm{b}}$ & $5.29 \pm 0.28^{\mathrm{c}}$ \\
\hline $\mathrm{C} 16: 0$ & $4.57 \pm 0.15^{\mathrm{a}}$ & $4.11 \pm 0.09^{b}$ & $2.64 \pm 0.13^{\mathrm{c}}$ \\
\hline C18:0 & $0.20 \pm 0.01^{\mathrm{a}}$ & $0.05 \pm 0.00^{\mathrm{b}}$ & $0.03 \pm 0.00^{\mathrm{b}}$ \\
\hline Total-SFA $^{1}$ & $13.70 \pm 0.51^{\mathrm{a}}$ & $12.51 \pm 0.27^{\mathrm{b}}$ & $8.34 \pm 0.43^{\mathrm{c}}$ \\
\hline $\mathrm{C} 16: 1$ & $3.53 \pm 0.12^{\mathrm{a}}$ & $3.62 \pm 0.11^{\mathrm{a}}$ & $2.21 \pm 0.13^{\mathrm{b}}$ \\
\hline C18:1 & $4.74 \pm 0.20^{\mathrm{a}}$ & $4.33 \pm 0.11^{\mathrm{b}}$ & $2.68 \pm 0.12^{\mathrm{c}}$ \\
\hline Total-MUFA $^{1}$ & $8.71 \pm 0.33^{\mathrm{a}}$ & $8.37 \pm 0.24^{\mathrm{a}}$ & $5.16 \pm 0.26^{\mathrm{b}}$ \\
\hline $\mathrm{C} 18: 2 \omega 6$ & $2.31 \pm 0.09^{\mathrm{a}}$ & $2.27 \pm 0.06^{\mathrm{a}}$ & $1.50 \pm 0.06^{\mathrm{b}}$ \\
\hline $\mathrm{C} 18: 3 \oplus 3$ & $4.28 \pm 0.26^{\mathrm{a}}$ & $5.38 \pm 0.36^{\mathrm{b}}$ & $2.41 \pm 0.22^{\mathrm{c}}$ \\
\hline $\mathrm{C} 18: 4 \oplus 3$ & $14.23 \pm 0.57^{\mathrm{a}}$ & $14.52 \pm 0.39^{\mathrm{a}}$ & $8.23 \pm 0.31^{\mathrm{b}}$ \\
\hline C20:4ळ6-AA & $0.08 \pm 0.00^{\mathrm{a}}$ & $0.07 \pm 0.01^{\mathrm{a}}$ & $0.05 \pm 0.01^{\mathrm{b}}$ \\
\hline C20:5๑3-EPA & $0.43 \pm 0.01^{\mathrm{a}}$ & $0.42 \pm 0.02^{\mathrm{a}}$ & $0.23 \pm 0.02^{\mathrm{b}}$ \\
\hline $\mathrm{C} 22: 5 \oplus 6$ & $1.03 \pm 0.08^{\mathrm{a}}$ & $1.05 \pm 0.04^{\mathrm{a}}$ & $0.67 \pm 0.06^{\mathrm{b}}$ \\
\hline C22:6@3-DHA & $10.07 \pm 0.23^{\mathrm{a}}$ & $9.58 \pm 0.32^{\mathrm{a}}$ & $5.24 \pm 0.17^{\mathrm{b}}$ \\
\hline Total-PUFA $^{1}$ & $34.63 \pm 0.93^{\mathrm{a}}$ & $35.03 \pm 1.05^{\mathrm{a}}$ & $19.49 \pm 0.71^{b}$ \\
\hline$\sum \oplus 3$ & $29.01 \pm 0.67^{\mathrm{a}}$ & $29.90 \pm 0.90^{\mathrm{a}}$ & $16.11 \pm 0.63^{\mathrm{b}}$ \\
\hline$\sum \omega 6$ & $5.45 \pm 0.27^{\mathrm{a}}$ & $5.00 \pm 0.15^{\mathrm{b}}$ & $3.27 \pm 0.08^{\mathrm{c}}$ \\
\hline$\sum \oplus 3: \sum \oplus 6$ & $5.33 \pm 0.14^{\mathrm{a}}$ & $5.99 \pm 0.07^{\mathrm{b}}$ & $4.93 \pm 0.10^{\mathrm{c}}$ \\
\hline$\sum \oplus 3$ HUFA & $10.50 \pm 0.24^{\mathrm{a}}$ & $10.00 \pm 0.35^{\mathrm{a}}$ & $5.47 \pm 0.18^{\mathrm{b}}$ \\
\hline DHA:EPA & $23.18 \pm 0.62^{\mathrm{a}}$ & $22.74 \pm 0.47^{\mathrm{a}}$ & $22.53 \pm 1.35^{\mathrm{a}}$ \\
\hline EPA:AA & $5.42 \pm 0.18^{\mathrm{a}}$ & $5.66 \pm 0.35^{\mathrm{a}}$ & $5.12 \pm 0.25^{\mathrm{a}}$ \\
\hline (SFA + MUFA):PUFA & $0.65 \pm 0.01^{\mathrm{a}}$ & $0.60 \pm 0.01^{\mathrm{b}}$ & $0.69 \pm 0.02^{\mathrm{c}}$ \\
\hline Total $^{1}$ & $57.03 \pm 1.71^{\mathrm{a}}$ & $55.91 \pm 1.48^{\mathrm{a}}$ & $32.99 \pm 1.29^{b}$ \\
\hline
\end{tabular}

Values (means $\pm \mathrm{SD}$ of four replications) in the same row not sharing a common superscript are significantly different $(p<0.05)$

${ }^{1}$ Contains some minor components not shown

${ }^{2}$ Contains $\omega 9$ and $\omega 7$ isomers

$S F A$, saturated fatty acid; $M U F A$, monounsaturated fatty acid; PUFA, polyunsaturated fatty acid; $L C-P U F A$, long-chain polyunsaturated fatty acid; $D W$, dry weight

(Table 5). The major fatty acids were myristic acid (C14:0), SDA and DHA, that together accounted for over $50 \%$ of total fatty acid content. The fatty acid pattern of this microalga was similar when grown in NS and NS3 media (Table 5). Moreover, in the treatment with the highest sulfur input, Isochrysis sp. fatty acids showed an analogous trend to R. marina, displaying a decrease of $42 \%$ in total fatty acids.

The assimilatory routes of sulfur converge in an array of compounds that also need carbon and nitrogen for their synthesis (Stefels 2000; Giordano and Raven 2014). Hence, the assimilatory routes of carbon, nitrogen, and sulfur are intertwined and the limitation of any of them stalls the production of the corresponding molecular pools (Falkowski and Raven 1997; Giordano and Raven 2014). Treatment NS6 triggered a decrease in $\mathrm{N} / \mathrm{S}$ and $\mathrm{C} / \mathrm{S}$ ratios in both Isochrysis sp. and $R$. marina. This might have led to an internal stoichiometric imbalance where the resources (e.g., carbon skeletons) required for sulfur assimilation were in short supply, limiting the growth and biochemical productivity.

The presence of EPA, DHA, and AA is essential in selecting microalgae for aquaculture purposes. However, due to the competitive interactions between them, the optimal requirements for each individual fatty acid must be taken into account when feeding live-prey in aquaculture (Luo et al. 2015). In this regard, all microalgae cultures, with the exception of $N$. gaditana cultivated in NS3, exceeded the recommended minimal ratios of EPA:AA $>5$ for flatfish larvae nutrition, and the sum of omega $3\left(\sum \omega 3\right)$ and omega 6 $\left(\sum \omega 6\right)$ rate higher than 2 for larval and juvenile oysters nutrition (Bell et al. 2003; Huerlimann et al. 2010). Regarding the DHA:EPA ratio, only Isochrysis sp. was above the recommended value (DHA: EPA > 2) for flatfish larvae nutrition (Bell et al. 2003).

\section{Conclusion}

The results of the present study evidence that the way by which microalgae respond to deviations to their normal operating conditions is species-specific and affects differently the carbon allocation in the three main macromolecular pools, as well as nutrients fluxes to the microalga cell. These differences may, for instance, determine the relationship between algae and their zooplanktonic predators in aquaculture and favor one microalgae species with respect to the others. Thus, the biochemical control on the production of these microorganisms to commercial purposes is crucial in order to assess these effects and understand these differences, even in nutrient replete conditions, bringing novel insights on microalgae enhancement.

Funding information This study was partially supported by the Oceanic Observatory of Madeira (M1420-01-0145-FEDER-000001-Observatório Oceânico da Madeira-OOM).

\section{References}

Andersen RA (2013) The microalgal cell. In: Richmond A, Hu Q (eds) Handbook of microalgal culture: applied phycology and biotechnology. Wiley, NY pp 3-20

Bell JG, McEvoy LA, Estevez A, Shields RJ, Sargent JR (2003) Optimising lipid nutrition in first-feeding flatfish larvae. Aquaculture 227:211-220

Bligh EG, Dyer WJ (1959) A rapid method of total lipid extraction and purification. Can J Biochem Physiol 37:911-917

Chen CY, Chen YC, Huang HC, Huang CC, Lee WL, Chang JS (2013) Engineering strategies for enhancing the production of eicosapentaenoic acid (EPA) from an isolated microalga Nannochloropsis oceanica CY2. Bioresour Technol 147:160-167 
Cohen Z, Vonshak A, Richmond A (1988) Effect of environmental conditions on fatty acid composition of the red alga Phorphyridium cruentum correlation to growth rate. J Phycol 24:328-332

Falkowski PG, Raven JA (1997) Making Cells. In: Falkowski PG, Raven JA (eds) Aquatic photosynthesis. Blackwell Science, Hoboken, pp 228-262

Feng D, Chen Z, Xue S, Zhang W (2011) Increased lipid production of the marine oleaginous microalgae Isochrysis zhangjiangensis (Chrysophyta) by nitrogen supplement. Bioresour Technol 102: 6710-6716

Fernandes T, Fernandes I, Andrade CAP, Cordeiro N (2016) Marine microalgae growth and carbon partitioning as a function of nutrient availability. Bioresour Technol 214:541-547

Fidalgo JP, Cid A, Torres E, Sukenik A, Herrero C (1998) Effects of nitrogen source and growth phase on proximate biochemical composition, lipid classes and fatty acid profile of the marine microalga Isochrysis galbana. Aquaculture 166:105-116

Fields MW, Hise A, Lohman EJ, Bell T, Gardner RD, Corredor L, Moll K, Peyton BM, Characklis GW, Gerlach R (2014) Sources and resources: importance of nutrients, resource allocation, and ecology in microalgal cultivation for lipid accumulation. Appl Microbiol Biotechnol 98:4805-4816

Giordano M (2013) Homeostasis: an underestimated focal point of ecology and evolution. Plant Sci 211:92-101

Giordano M, Raven JA (2014) Nitrogen and sulfur assimilation in plants and algae. Aquat Bot 118:45-61

Harwood JL, Guschina IA (2009) The versatility of algae and their lipid metabolism. Biochimie 91:679-684

Ho T-Y, Quigg A, Finkel ZV, Milligan AJ, Wyman K, Falkowski PG, Morel FMM (2003) The elemental composition of some marine phytoplankton. J Phycol 39:1145-1159

Huerlimann R, Nys R, Heimann K (2010) Growth, lipid content, productivity, and fatty acid composition of tropical microalgae for scale-up production. Biotechnol Bioeng 107:245-257

Huerlimann R, Steinig EJ, Loxton H, Zenger KR, Jerry DR, Heimann K (2014) Effects of growth phase and nitrogen starvation on expression of fatty acid desaturases and fatty acid composition of Isochrysis aff. galbana (TISO). Gene 545:36-44

Irihimovitch V, Yehudai-Resheff S (2008) Phosphate and sulfur limitation responses in the chloroplast of Chlamydomonas reinhardtii. FEMS Microbiol Lett 283:1-8

Karemore A, Pal R, Sen R (2013) Strategic enhancement of algal biomass and lipid in Chlorococcum infusionum as bioenergy feedstock. Algal Res 2:113-121

Karlsen O, van der Meeren T, Ronnestad I, Mangor-Jensen A, Galloway TF, Kjorsvik E, Hamre K (2015) Copepods enhance nutritional status, growth and development in Atlantic cod (Gadus morhua L.) larvae - can we identify the underlying factors? PeerJ 3:e902

Kim CW, Sung MG, Nam K, Moon M, Kwon JH, Yang JW (2014) Effect of monochromatic illumination on lipid accumulation of
Nannochloropsis gaditana under continuous cultivation. Bioresour Technol 159:30-35

Koller M, Muhr A, Braunegg G (2014) Microalgae as versatile cellular factories for valued products. Algal Res 6:52-63

Lepage G, Roy CC (1986) Direct transesterification of all classes of lipids in a one-step reaction. J Lipid Res 27:114-120

Luo L, Ai L, Li T, Xue M, Wang J, Li W, XiufengWu LX (2015) The impact of dietary DHA/EPA ratio on spawning performance, egg and offspring quality in Siberian sturgeon (Acipenser baeri). Aquaculture 437:140-145

Mayers JJ, Flynn KJ, Shields RJ (2014) Influence of the N:P supply ratio on biomass productivity and time-resolved changes in elemental and bulk biochemical composition of Nannochloropsis sp. Bioresour Technol 169:588-595

Mera R, Torres E, Abalde J (2016) Effects of sodium sulfate on the freshwater microalga Chlamydomonas moewusii: implications for the optimization of algal culture media. J Phycol 52:75-88

Mizuno Y, Sato A, Watanabe K, Hirata A, Takeshita T, Ota S, Sato N, Zachleder V, Tsuzuki M (2013) Kawano S (2013) Sequential accumulation of starch and lipid induced by sulfur deficiency in Chlorella and Parachlorella species. Bioresour Technol 129:150 155

Montechiaro F, Hirschmugl CJ, Raven JA, Giordano M (2006) Homeostasis of cell composition during prolonged darkness. Plant Cell Environ 29:2198-2204

Muhlroth A, Li K, Rokke G, Winge P, Olsen Y, Hohmann-Marriott MF, Vadstein O, Bones AM (2013) Pathways of lipid metabolism in marine algae, co-expression network, bottlenecks and candidate genes for enhanced production of EPA and DHA in species of Chromista. Mar Drugs 11:4662-4697

Palmucci M, Ratti S, Giordano M (2011) Ecological and evolutionary implications of carbon allocation in marine phytoplankton as a function of nitrogen availability: a fourier transform infrared spectroscopy approach. J Phycol 47:313-323

Rocha JMS, Garcia JEC, Henriques MHF (2003) Growth aspects of the marine microalga Nannochloropsis gaditana. Biomol Eng 20:237242

Simionato D, Block MA, La Rocca N, Jouhet J, Maréchal E, Finazzi G, Morosinottoa T (2013) The response of Nannochloropsis gaditana to nitrogen starvation includes de novo biosynthesis of triacylglycerols, a decrease of chloroplast galactolipids, and reorganization of the photosynthetic apparatus. Eukaryot Cell 12:665-676

Stefels J (2000) Physiological aspects of the production and conversion of DMSP in marine algae and higher plants. J Sea Res 43:183-197

Sukenik A (1991) Ecophysiological considerations in the optimization of eicosapentaenoic acid production by Nannochloropsis sp. (Eustigmatophyceae). Bioresour Technol 35:263-269

Publisher's note Springer Nature remains neutral with regard to jurisdictional claims in published maps and institutional affiliations. 